\title{
嫌気無酸素回分式リアクターを用いた 都市下水からの栄養塩除去とリン回収
}

\author{
坂本 健- ${ }^{1} \cdot$ 幡本 将史 $^{1} \cdot$ 高橋 優信 $^{2} \cdot$ 久保田 健吾 $^{2} \cdot$ 荒木 信夫 $^{3}$ \\ 山崎 慎一 ${ }^{4} \cdot$ 大久保 $\quad$ 努 ${ }^{5} \cdot$ 上村 繁樹 $^{5} \cdot$ 原田 秀樹 ${ }^{2} \cdot$ 山口 隆司 ${ }^{1 *}$ \\ ${ }^{1}$ 長岡技術科学大学大学院工学研究科環境システム工学専攻（†940-2188新潟県長岡市上富岡町1603-1) \\ ${ }^{2}$ 東北大学大学院工学研究科土木工学専攻（ T980-8579宮城県仙台市青葉区荒巻字青葉6-6-06） \\ ${ }^{3}$ 長岡工業高等専門学校（干940-0817新潟県長岡市西片貝町888） \\ 4高知工業高等専門学校（干783-8508高知県南国市物部乙200番1） \\ ${ }^{5}$ 木更津工業高等専門学校（干292-0041千葉県木更津市清見台東2-11-1） \\ * E-mail: ecoya@vos.nagaokaut.ac.jp
}

\begin{abstract}
脱窒性リン蓄積細菌 (DPAOs) を用いた嫌気・無酸素回分式リアクター $\left(\mathrm{A}_{2} \mathrm{SBR}\right)$ と物理化学的リン回収 法によるリン回収リアクターを用い, 都市下水処理水の高度処理およびリン回収実験を行った. その結果, 流入下水中からのリン除去率は $83 \pm 6.3 \%$, 窒素除去率は75 $15 \%$ であり， $\mathrm{A}_{2} \mathrm{SBR}$ 用いた下水からの栄養塩 除去システムの構築に成功した. Fluorescence in situ hybridization法を用いた $\mathrm{A}_{2} \mathrm{SBR}$ 槽内のリン蓄積細菌 (PAOs) の存在割合を定量したところ，安定的な処理が行われている期間では，PAOsの存在割合が $15 \%$ 以 上であることが確認された。 また，リン回収リアクターにより，溶液中から $98 \%$ リンを除去することが できた. $\mathrm{A}_{2} \mathrm{SBR}$ で濃縮したリン溶液に物理化学的リン回収法を適応することで, 流入下水中のリン量に対 して29\%のリンを回収することができた.
\end{abstract}

Key Words : UASB $+D H S, A_{2} S B R, P$ removal, $P$ recovery, $N$ removal, hydroxyapatite

\section{1. はじめに}

湖沼等の閉鎖性水域における水質污染は，産業廃水や 生活排水中に含有するリンや窒素等の栄養塩が原因の 1 つである.また，リンは化石資源であり，日本は肥料等 の製造に用いるリン鉱石の全量を輸入に依存している ${ }^{1)}$. 近年では, 急激な人口増加による食糧需要の増加に伴い, 肥料・飼料等に用いられる鉱石の価格は高騰する傾向に ある. 食物生産に利用されたリンの $2 / 3$ 以上がし尿等とし て下水に流出しているという推計もあることから ${ }^{2)}$, 現 在, 下水からのリン回収が注目されている.

下水からの生物学的手法を用いた栄養塩除去法として, ポリリン酸蓄積細菌 (Polyphosphate Accumulating Organisms : PAOs) と脱窒菌を用いた方法や, 窒素とリン の同時除去を目的とした嫌気/無酸素/好気 (Anaerobic / Anoxic / Oxic : $\mathrm{A}_{2} \mathrm{O}$ ) 法等がある3). しかし, これらの手法 にはエアレーションが必要であり, ランニングコストが 非常に大きくなるという問題がある.
我々の研究グループでは, 省エネルギー・低コスト型 の下水処理システムとして上昇流嫌気性污泥床 (Up-flow Anaerobic Sludge Blanket : UASB) 法と下降流䀣 垂型スポンジ (Down-flow Hanging Sponge : DHS) 法を用 いたシステムを開発している ${ }^{4)-6)}$. 本システムは低有機 物濃度の下水処理において, 卓越した有機物除去性能と 高い硝化性能を有している. また, 本システムはエアレ ーションを必要としないためエネルギー消費が少なく, 必要敷地面積も小さいうえ, 余剩污泥発生量も少ないと いう利点がある．しかしながら，下水中に含有する栄養 塩の除去については, その処理機構を備えていないため, 高度処理を備えたシステムの構築が望まれる。

そこで我々は, UASB+DHS処理システムの高い有機物 除去性能と硝化性能を活かしつつ, 高度処理を行うため に, PAOsの一種である脱窒性リン蓄積細菌 (Denitrifying Polyphosphate Accumulating Organisms : DPAOs) を用いた 都市下水の低コス卜高度処理システムの開発を行ってい る. DPAOsは硝酸を電子受容体として利用し，ポリリン 
酸を菌体内に蓄積する微生物である.また, PAOsと脱窒 細菌を用いた手法を比較すると, 余剩污泥の発生量や必 要有機物量が少ないという利点がある7 $。$ DPAOsの培養 には嫌気と無酸素のサイクルが必要であり，これを実現 するため, 本研究では嫌気・無酸素回分式リアクター (Anaerobic/Anoxic Sequencing Batch Reactor : $\mathrm{A}_{2} \mathrm{SBR}$ ) UASB+DHS システムの後段に設置して長期連続運転を 行い, リン除去および脱窒性能の評価を行った.

また, DPAOsはポリリン酸を高濃度で細胞内に蓄積す るため, 污泥からのリン回収が可能であると考えられる. これまでにUASB+DHS+A $\mathrm{A}_{2} \mathrm{SBR}$ ンステムを用いたリン除 去は研究されているが8), 蓄積したリンの回収に関する 報告は無い. そこで, 本研究では $\mathrm{A}_{2} \mathrm{SBR}$ に蓄積したリン を物理化学的リン回収法であるヒドロキシアパタイト (Hydroxyapatite : HAP) 法を用いた回収実験を行い, リン 回収率を評価することでUASB+DHS+A 2 SBRシステムに おけるリン回収の適応性の調査を行った.

\section{2. 実験方法}

(1) UASB+DHS下水処理システム

本研究では, 高さ $4.7 \mathrm{~m}$, 全容量 $1,178 \mathrm{~L}$ UASBリアク ターと高さ $4.7 \mathrm{~m}$, スポンジ総容積 $454 \mathrm{~L}$ ○DHSリアクタ 一を組み合わせたUASB+DHS下水処理システムを用い た9).UASB+DHSシステムにはスクリーンと沈殿槽を通 過した後の実下水を流入水として供給した. UASB DHSの水理学的滞留時間 (Hydraulic retention time : HRT) は，それぞれ8時間と6時間に設定した。

\section{(2) $\mathrm{A}_{2} \mathrm{SBR}+\mathrm{HAP}$ 生成リアクター}

$\mathrm{A}_{2} \mathrm{SBR}$ はUASB+DHSシステムの後段に設置し, DHS 処理水の高度処理を行った. また, $\mathrm{A}_{2} \mathrm{SBR}$ 後段にHAP 生成リアクターを設置し， $\mathrm{A}_{2} \mathrm{SBR}$ に蓄積したリンの回収 を行った。 $\mathrm{A}_{2} \mathrm{SBR}$ と HAP生成リアクターの概要図を図-1 に示寸.

$\mathrm{A}_{2} \mathrm{SBR}$, 高さ $0.9 \mathrm{~m}$, 外径 $0.6 \mathrm{~m}$, 全容量 $200 \mathrm{~L}$, 槽内 水量は50 Lで，槽内は嫌気環境を維持した. $\mathrm{A}_{2} \mathrm{SBR}$ は 360 分を1サイクルとし，90分の嫌気条件と270分の無酸素条 件で構成した. $\mathrm{A}_{2} \mathrm{SBR}$ の運転サイクルを図-2 (A) に示す. サイクル開始時 (0分) に炭素源として酶酸ナトリウム 溶液 (流入リン濃度に対するCOD/P比は $25 \mathrm{~g}-\mathrm{COD} / \mathrm{g}-\mathrm{P}$ ) を添加し，摚找を開始して槽内を嫌気環境とした。 UASB+DHS システムによって有機物除去と硝化を行っ た都市下水処理水を, 90分に槽内に50 L流入し, 槽内を 無酸素環境とした. $\mathrm{A}_{2} \mathrm{SBR}$ の流入水は, DHSの後段に50 Lの貯水タンクを設置し, 毎サイクルの 90 分毎にDHS処
理水を $\mathrm{A}_{2} \mathrm{SBR}$ に流入した. 290 分に槽内の擋汼を停止して 污泥を沈降させ, 350分に分離した上澄夕50 Lを排水した. $\mathrm{A}_{2} \mathrm{SBR}$ 槽内の $\mathrm{pH}$ は, 添加する酢酸ナトリウム溶液の $\mathrm{pH}$

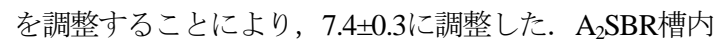
の污泥濃度は, 污泥を継続的に引抜くことにより, 約 2,000 mg/Lに調整した. $\mathrm{A}_{2} \mathrm{SBR}$ の植種污泥には活性污泥 を用いた。

$\mathrm{A}_{2} \mathrm{SBR}$ 処理水からのリン回収を目的に $\mathrm{A}_{2} \mathrm{SBR}$ 後段に HAP生成リアクターを設置した. HAP生成リアクターは, 高さ $0.4 \mathrm{~m}$, 外径 $0.3 \mathrm{~m}$, 全容量 $30 \mathrm{~L}$ のタンクを用いた.

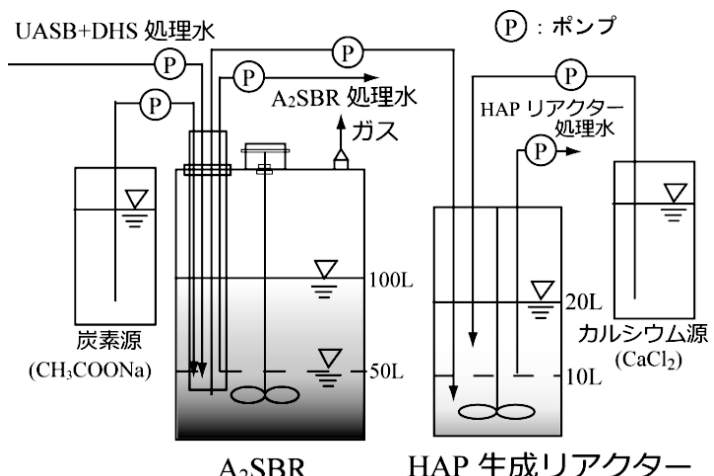

図-1 $\mathrm{A}_{2} \mathrm{SBR}$ と HAP 生成リアクターの概要図

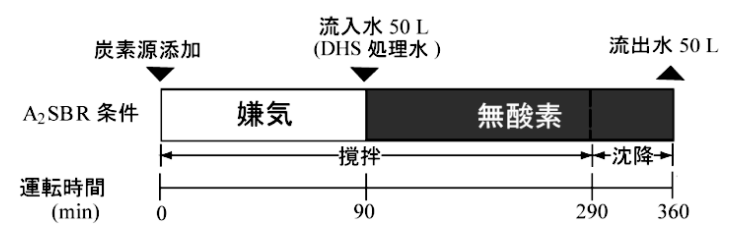

(A) $\mathrm{A}_{2} \mathrm{SBR}$ の運転サイクル (1 サイクル 360 分)

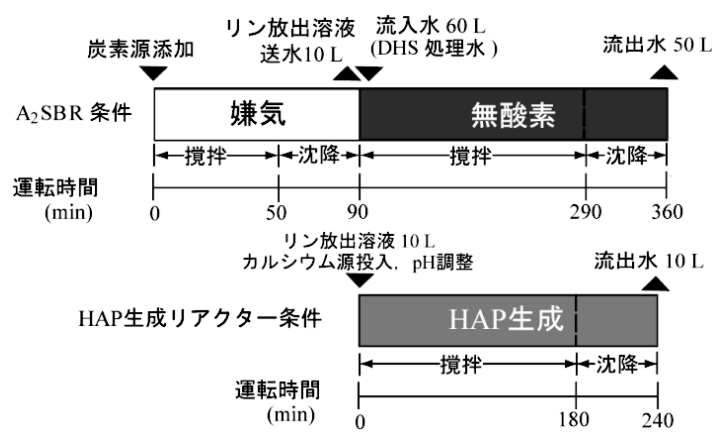

(B) HAP 生成リアクター運転時の $\mathrm{A}_{2} \mathrm{SBR}$ の運転サイ クルと HAP 生成リアクターの運転サイクル (1サ イクル 240 分)

図-2 $\mathrm{A}_{2} \mathrm{SBR}$ および HAP 生成リアクターの運転サイ クル 
HAP生成リアクター運転時には, $\mathrm{A}_{2} \mathrm{SBR}$ は運転サイクル を変更して運転した，HAP生成リアクター運転時の $\mathrm{A}_{2} \mathrm{SBR}$ の運転サイクルと, HAP生成リアクターの運転サ イクルを図-2 (B) に示寸. HAP生成リアクターの流入水 は， $\mathrm{A}_{2} \mathrm{SBR}$ における嫌気条件終了時のリン放出溶液とし た. $\mathrm{A}_{2} \mathrm{SBR}$ の嫌気条件下では, DPAOsの有機物摂取に伴 って液中にリンが放出されている.この放出されたリン を回収するために, $\mathrm{A}_{2} \mathrm{SBR}$ のサクル開始後50分で擋抖 を停止し，85分の上澄み $10 \mathrm{~L}$ tHAP生成リアクターに送 水した. 送水後, HAP生成リアクターにカルシウム源と して塩化カルシウム溶液 (化学量論から Ca/P比は2.15 g-Ca/g-P) を添加し, pHを9.0付近に調整し，3時間擋拌す ることでHAPを生成した. 生成したHAPは擋拌を停止し て沈降分離し, 自然乾燥して回収した. HAP生成リアク ターの運転は $\mathrm{A}_{2} \mathrm{SBR} の$ 運転が安定したのを確認後,

$\mathrm{A}_{2} \mathrm{SBR}$ の運転220-250日の期間に，10日に1回の割合で合 計3回実施した.

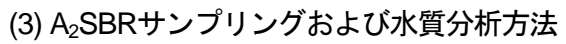

$\mathrm{A}_{2} \mathrm{SBR}$ の流出水の分析用サンプルは, $\mathrm{A}_{2} \mathrm{SBR}$ 運転サ イクルにおける350分で流出する処理水を採取した.また, 流入水はDHS流出水とした. $\mathrm{A}_{2} \mathrm{SBR}$ の槽内污泥は, $\mathrm{A}_{2} \mathrm{SBR}$ 処理水の排水終了直後の槽内容量が50 Lの時に, $\mathrm{A}_{2} \mathrm{SBR}$ 槽内を擋挥して採取した. 溶解性成分の分析については, 保留粒子径 $0.4 \mu \mathrm{m}$ のガラス䋊維濾紙 (GB-140, ADVANTEC) を通過した試料を用いた。

全リン濃度と溶解性リン濃度の分析には, 多項目水質 分析計 (DR-2800, HACH) を用いた. 窒素濃度の分析に は, まず亜硝酸, 硝酸, アンモニア濃度を, 高速液体ク ロマトグラフ (HPLC ; Shimadzu LC-20-ADsp) を用いて 分析した. 次に, 多項目水質分析計 (DR-2800, HACH) を 用いてケルダール窒素濃度を測定し，アンモニア濃度か ら有機態濃度を算出し, 全窒素濃度を算出した。 その他 の分析項目に関しては，下水試験方法に準拠して行った 10).

\section{(4) Fluorescence in situ hybridization (FISH) 法}

FISH法はAmannら ${ }^{11)}$ の方法に準拠して行った. 使用し た蛍光標識DNAプローブを表-1に示寸. プローブはCy3 およびAlexa Fluor 488標識されたものを用いた． FISH法 を適用したサンプルは，裉色防止剂 (ProLong Gold Antifade Reagent with DAPI, Invitrogen) で封入後, 顕微鏡 観察に供した。観察には, 落射蛍光顕微鏡BX-53 (OLYMPUS) を用い, 写真の撮影にはCCDカメラ VB-7010 (KEYENCE) を用いた. PAOsの存在割合は, PAO mix プローブからの蛍光で得られる菌体数を EUB338 mixプローブによる蛍光で得られる菌体数で除
して算出した. EUB338 mixプローブによる蛍光で得られ る菌体数は 1000 細胞以上となるように計測した.

\section{3. 実験結果および考察}

\section{(1) $A_{2} S B R$ 処理性能}

$\mathrm{UASB}+\mathrm{DHS}+\mathrm{A}_{2} \mathrm{SBR}$ システムの各プロセスにおける栄 養塩の濃度変化を図-3に示す，また， $\mathrm{A}_{2} \mathrm{SBR}$ における栄 養塩濃度および除去率の経日変化を図-4に示寸，運転開 始100日目までは, 嫌気条件時での炭素源摂取やリン放出 および無酸素条件時でのリン蓄積や脱窒といった DPAOsの代謝が安定していないため, スタートアップ期 間とした。処理性能を測定した期間は, DPAOsの代謝が 安定した実験開始100日目から260日目とした。リン濃度

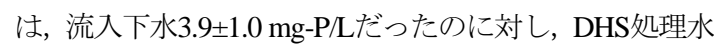

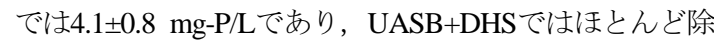
去されていなかった。 それに対し， $\mathrm{A}_{2} \mathrm{SBR}$ 処理水では

表-1 $\mathrm{A}_{2} \mathrm{SBR}$ 保持污泥内の微生物解析に用いたプロ ーブ

\begin{tabular}{lllc}
\hline Probe & Sequence $\left(5^{\prime}-\right.$-3' $\left.^{\prime}\right)$ & Target & Reference \\
\hline \hline EUB338 & GCTGCCTCCCGTAGGAGT & Most Bacteria & 11 \\
EUB338- II & GCAGCCACCCGTAGGTGT & Most Bacteria & 12 \\
EUB338-III & GCTGCCACCCGTAGGTGT & Most Bacteria & 12 \\
PAO462 & CCGTCATCTACACAGGGTATT & Accumulibacter & 13 \\
PAO651 & CCCTCTGCCAAACTCCAC & Accumulibacter & 13 \\
PAO846 & GTTAGCTACGGCACTAAAAGG & Accumulibacter & 13 \\
\hline
\end{tabular}



図-3 UASB+DHS+ $\mathrm{A}_{2} \mathrm{SBR}$ の平均栄養塩濃度

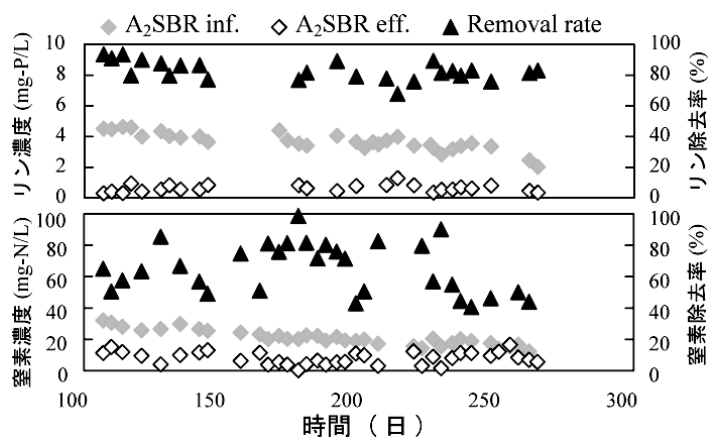

図-4 $\mathrm{A}_{2} \mathrm{SBR}$ における栄養塩除去の経日変化 


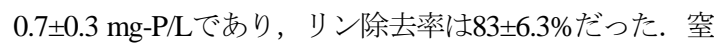
素濃度は，流入下水における全窒素濃度が $36 \pm 23 \mathrm{mg}-\mathrm{N} / \mathrm{L}$ だったのに対し, UASB処理水では $21 \pm 4.9 \mathrm{mg}-\mathrm{N} / \mathrm{L}$ なり, $\mathrm{A}_{2} \mathrm{SBR}$ 処理水では8.4 4 4.0 $\mathrm{mg}-\mathrm{N} / \mathrm{L}$ なった。この時, UASB処理水での硝酸濃度が $0.1 \mathrm{mg}-\mathrm{N} / \mathrm{L}$ 程度であったの に対し, DHS処理水の硝酸濃度は17.3 mg-N/Lであり，硝 化反応を確認できた (図-3)．また, DHS処理水の全窒素 濃度がUASB処理水に対して $38 \%$ 低下していることから, DHS槽内でも脱窒反応が起こっていると考えられた.



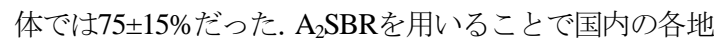

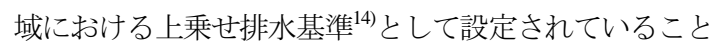
が多いリン濃度 $1 \mathrm{mg}-\mathrm{P} / \mathrm{L}$ 以下, 窒素濃度 $10 \mathrm{mg}-\mathrm{N} / \mathrm{L}$ 以下を 達成することができた。これらの結果から， $\mathrm{A}_{2} \mathrm{SBR} に よ$ ってDHS処理水に残留したリンと窒素の同時除去が可 能であり, 最終処理水は水質基準を達成していることが 確認された.

\section{(2) $A_{2} S B R$ 水質プロファイル}

$\mathrm{A}_{2} \mathrm{SBR}$ の水質プロファイル測定の結果を図-5に示す. (A) は運転32日目，(B) は運転85日目，(C) は運転128日 目，(D) は運転226日目のデータを示す. 運転32日目と 85 日目はスタートアップ期間であり，32日目ではDPAOsの 代謝が確認できなかった。 また，85日目では，嫌気条件 終了時には有機物濃度が $24 \mathrm{mg}-\mathrm{COD} / \mathrm{L}$ 残留し, 無酸素条 件終了時には硝酸濃度が7.1 mg-N/L, リン濃度が 1.67 mg-P/L残留した。 また，85日目の無酸素条件終了時の全 窒素濃度は11.6 mg-N/Lであり, 除去目標である 10 mg-N/Lを超過していた。同様に, 無酸素条件終了時のリ ン濃度も除去目標の $1 \mathrm{mg}-\mathrm{P} / \mathrm{L}$ 超過しており，85日目の 窒素除去は不十分であったと考えられる. 運転が安定し た128日目では，嫌気条件時には最高で58 mg-P/Lのリン を放出し, 無酸素条件終了時には0.5 mg-P/Lまでのリン 除去を確認でき，十分なリン放出とリン除去が行われて いた. また，226日目でも同様のリン放出と除去が確認さ れたが，128日目よりも放出量が低く, 窒素と有機物の除 去率も低かった。この原因として， $\mathrm{A}_{2} \mathrm{SBR}$ 槽内の污泥濃 度に対する污泥中のリン濃度の割合は，128日目が $8.1 \%$, 226日目が6.5\%であり，226日目では放出リン量が十分に 確保できなかったことが処理性能低下の原因であると考 えられた.

\section{(3) $A_{2} S B R$ 槽内におけるPAOsの存在割合の経日変化}

FISH法によってPAOsを検出した結果, 検出したPAOs の多くは他の報告と同様にクラスターを形成していた ${ }^{15)}$.

FISH法によるPAOsの定量によって得られた， $\mathrm{A}_{2} \mathrm{SBR}$ 槽内におけるPAOsの存在割合の経日変化を図-6に示す.
$\mathrm{A}_{2} \mathrm{SBR}$ 槽内のPAOsの存在割合は, スタートアップ期間の 前半では3-4\%と低い值を示した。しかし，スタートアッ プ未期の運転88日目での存在割合は18\%であり，それ以 降から206日目までの存在割合は15-18\%程度で推移した。 運転243日目での存在割合は29\%まで上昇した. 様々な処 理方式における実下水処理場污泥に含まれるPAOsの存

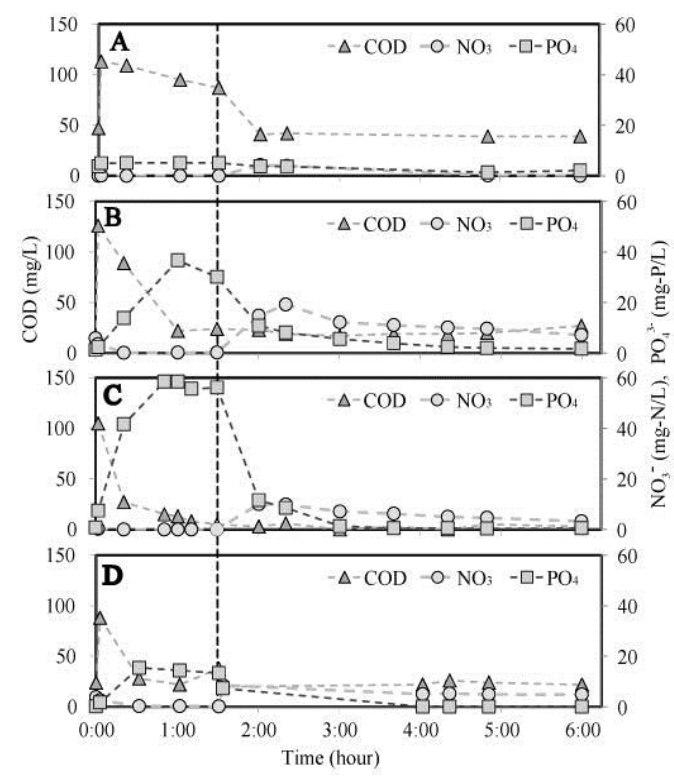

図-5 $\mathrm{A}_{2} \mathrm{SBR}$ の水質プロファイル測定による 1 サイクル 内の水質変化 (A) 運転 32 日目 (B) 運転 85 日目 (C) 運転 128 日目 (D) 運転 226 日目

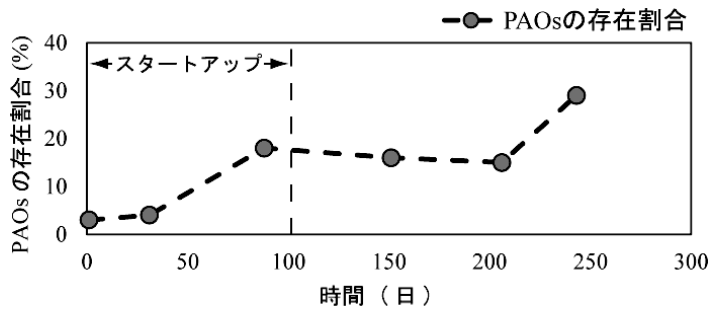

図-6 $\mathrm{A}_{2} \mathrm{SBR}$ 槽内における PAOs の存在割合の経日変化

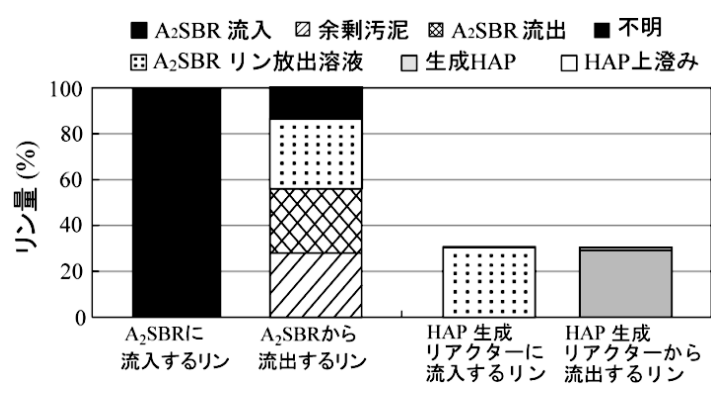

図-7 $\mathrm{A}_{2} \mathrm{SBR}$ と HAP 生成リアクターにおけるリンの マスバランス 
在割合は4-20\%程度 ${ }^{16-19)}$ とされており， $\mathrm{A}_{2} \mathrm{SBR}$ でも同程 度のPAOsを保持していた. これらの結果と水質プロファ イルの結果を比較した場合, $\mathrm{A}_{2} \mathrm{SBR}$ 槽内のPAOsの存在割 合が $15 \%$ 程度以上あれば，安定的な処理が実現可能であ ると考えられた. また, 実験期間後半の運転 243 日目にお いてPAOsの存在割合が $29 \%$ まで増加したが, この要因の ひとつとして季節変動に伴う気温の低下が考えられる.

PAOsは $20^{\circ} \mathrm{C} よ り$ 低い温度の方が, 他の細菌との競合にお いて有利であるとの報告もあり ${ }^{20)}$ ，水温が $26.5^{\circ} \mathrm{C}$ 運転 151日目と比較して，運転243日目 (11月29日) の水温は $16.2^{\circ} \mathrm{C}$ 低下しており, PAOsの存在割合が増加した可能 性が考えられた。

\section{(4) HAP生成リアクターのリン回収性能}

HAP生成リアクターを用いたリン回収実験における1 日あたりのリンのマスバランスを図-7に示す。1日の $\mathrm{A}_{2} \mathrm{SBR}$ 流入のリン量を628 $53.4 \mathrm{mg}-\mathrm{P} / \mathrm{day}(100 \%)$ とした 時, リン除去後 $\left(\mathrm{A}_{2} \mathrm{SBR}\right.$ の無酸素条件終了時) の $\mathrm{A}_{2} \mathrm{SBR}$ 流出のリン量が $177 \pm 74.9 \mathrm{mg}-\mathrm{P} / \mathrm{day}(28 \%) ， \mathrm{~A}_{2} \mathrm{SBR}$ の污泥 濃度調整に伴って発生する余剩污泥に含まれるリン量は $176 \pm 57.2 \mathrm{mg}-\mathrm{P} / \mathrm{day}$ (28\%) だった. また, リン放出後 ( $\mathrm{A}_{2} \mathrm{SBR}$ の嫌気条件終了時) のHAP生成リアクターに送 水したリン放出溶液のリン量は187 $\pm 27.0 \mathrm{mg}-\mathrm{P} / \mathrm{day}(30 \%)$ であり，生成したHAPのリン量は183 $440.6 \mathrm{mg}-\mathrm{P} / \mathrm{day}$ (29\%) であり, 未回収のリンの多くは余剩污泥として系 外一排出されていた. また, この時, HAP生成リアクタ 一におけるリン回收率は98\%だった。 以上の結果から,

HAP生成リアクターの運転により, $\mathrm{A}_{2} \mathrm{SBR}$ 槽内に蓄積さ れるリンを継続的に回収することができると考えられた. 従来, リン濃度 $4 \mathrm{mg}-\mathrm{P} / \mathrm{L}$ 程度の溶液からのリン回収は, より低濃度において沈殿しやすいアルミニウム化合物の 添加が一般的であるが，回収污泥の施肥利用等を考慮す ると，カルシウム添加でもリン回収できることは実用化 に向けて意義がある.

\section{(5) 既存のリン回収技術との回収率の比較}

都市下水からのリン回収方法には, リン蓄積污泥を焼 却して回収寸る方法や, 溶液中のリンを凝集剂や物理化 学的手法を用いて回収する方法がある ${ }^{21)}$. また, 溶液中 からのリン回収には, PAOsの代謝を利用して污泥中から 濃縮したリンを放出させる方法等がある21).

下水溶液中からのリン回収方法のうち, 凝集郕として ポリ塩化アルミニウム (PAC) を用いた場合, 50-90\%程 度のリン回収率もしくはリン除去率を示すと報告されて いる22-24)。また, この中で, 市原ら ${ }^{22)}$ はPACを用いたリ ン回収実験により, リン酸塩に対するPACの比が 0.2 $\mathrm{g}-\mathrm{PO}_{4}{ }^{3-} / \mathrm{g}-\mathrm{Al}$ の時，9割以上のリン除去率を示したと報告
している.

加藤ら ${ }^{25)}$ は, リン蓄積污泥からの最適なリン回収方法 を検討するため, 各種のリン抽出方法と回収方法, およ びリン蓄積污泥種の組み合わせを検証した. その結果, 余剰濃縮污泥において, 超音波による抽出法とカルシウ ムを用いた凝集沈殿法の組み合わせが，最も低コストか つ効率的なリン回収方法であると報告している. この方 法による回収率は, $45.2 \%$ と本研究よりも高い值を示し

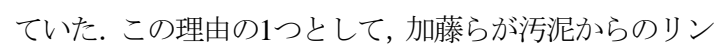
抽出に用いた超音波抽出法が, 本研究で用いたPAOsの代 謝を利用した方法よりも高効率であったことが考えられ る.

$\mathrm{A}_{2} \mathrm{SBR}$ と HAP生成リアクターを用いた本実験におけ るリン回収方法は, リン濃縮污泥からのリン放出と, 放 出後の溶液からの物理化学的リン回収法で構成されてい る. HAP法を用いた物理化学的リン回収法は, リン放出 溶液からのリン回収率が $98 \%$ と高く，凝集剂を用いた手 法に匹敵しているため, 十分に優れたリン回収方法だと 言える.にもかかわらず， $\mathrm{A}_{2} \mathrm{SBR}$ のリン収支におけるリ ン回収率が29\%と低かった原因として, 污泥からのリン 放出法に問題があったと考えられる. 本実験でのリン放 出法は, 有機物を投入することによるDPAOsのリン放出 作用を利用し， $\mathrm{A}_{2} \mathrm{SBR}$ のンステム内で行った. しかし， 溶液中に放出されたリン量は全体の $30 \%$ 未満であり, こ のことがシステム全体としてのリン回収率が低くなって しまった原因と考えられる. したがって, 余剩污泥中か らのリン回収率がシステム全体でのリン回収率の向上に 必要不可欠であるため, 今後は物理的手法やリン放出槽 の設置等, リン蓄積污泥からのリン回収手法の検討を行 っていく必要がある.

\section{4. 結論}

1) UASB+DHS+A $\mathrm{A}_{2} \mathrm{SBR}$ ンステム全体における処理性能は, リン除去率が $83 \pm 6.3 \%$ ，窒素除去率が75 $715 \%$ だった.

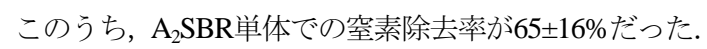
2) 本実験における条件では, 安定した処理を行うまでに 100 日程度のスタートアップ期間が必要であることが わかった。しかし，污泥中に含有するリン濃度が低い 場合, DPAOsの代謝における放出リン量が低下し，十 分なリン除去と脱窒が行われないことがわかった.

3) PAOsの存在割合を求めた結果, PAOsの存在割合が全 細菌数の $15 \%$ 程度であれば, 安定的な処理が実現可能 であると考えられた。

4) HAP生成リアクターによるリン回収率は, $\mathrm{A}_{2} \mathrm{SBR}$ に流 入するリン量に対して $29 \%$ でった。しかし， $\mathrm{A}_{2} \mathrm{SBR}$ 
に流入するリンの多くは余剩污泥として系外一排出し ており，今後は污泥からのリン回収技術の開発が必要 である。

謝辞 : 本研究の一部は, JST-JICA地球規模課題対応国際 科学技術協力事業「エネルギー最小消費型の下水処理技 術の開発」から一部助成を受けて遂行しました。ここに 記して深謝致します。

\section{参考文献}

1) Yokoyama K., Kubo H., Nakajima K., and Nagasaka T.: A material flow analysis of phosphorus in Japan. Journal of Industrial Ecology Vol.13, No.5, pp.687-705, 2009.

2) 萩野隆生, 平島 剛: 下水污泥からのリン回収プロセスの開 発. 環境資源工学 52,pp.172-182, 2005.

3) 常田 聡, 安 祚煥, 大道智孝, 大野高史, 平田 彰: 脱窒性 リン蓄積細菌を利用した新しい高度排水処理プロセス, 水環 境学会誌, Vol.25, No.12, pp.751-755, 2002.

4) Tandukar, M., Uemura, S., Ohashi, A., and Harada, H.: Combining UASB and the "fourth generation" down-flow hanging sponge reactor for municipal wastewater treatment. Water Science Technology, Vol.53, No.3, pp.209-218, 2006.

5) Tandukar, M., Ohashi, A., and Harada, H.: Performance comparison of a pilot-scale UASB and DHS system and activated sludge process for the treatment of municipal wastewater. Water Research, Vol.41, pp.2697-2705, 2007.

6) Onodera T., Matsunaga K., Kubota K., Taniguchi R., Harada H., Syutsubo K., Okubo T., Uemura S., Araki N., Yamada M., Yamauchi M., and Yamaguchi T.: Characterization of the retained sludge in a down-flow hanging sponge (DHS) reactor with emphasis in its low excess sludge production. Bioresource Technology, Vol.136, pp.169-175, 2013.

7) T. Kuba, M. C. M. van Loosdrecht.: phosphorus and nitrogen removal with minimal COD requirement by integration of denitrifying dephosphatation and nitrification in a two-sludge system. Water Research, Vol.30, No.7, pp.1702-1710, 1996.

8) 出濱和弥, 小野心也, 高橋優信, 幡本将史, 山口隆司 : 嫌気 無酸素回分式リアクターを用いた生物学的栄養塩処理プロ セスの開発. 第 46 回日本水環境学会年会講演集, pp.46, 2012.

9) 松永健吾, 小野寺崇, 上村繁樹, 山田真義, 山内正仁, 高橋優 信, 久保田健吾, 原田秀樹, 山口隆司:下水処理 UASB 後段の DHS における余㮃污泥量の抑制要因の評価. 環境工学研究論 文集, Vol.46, pp.623-627, 2009.

10) (社) 日本下水道協会 : 下水試験方法上巻, 1997.

11) Amann, R. I.: In situ identification of micro-organisms by whole cell hybridization with rRNA-targeted nucleic acid probes, In Molecular microbial ecology manual, pp. 99.1.15 Edited by A.D.L
Akkermans \& J.D. van Elsas. London : Kluwer Academic

Publishers, 1995.

12) Daims, H., A. Bruhl, R. Amann, K. H. Schleifer, and M.: Wagner. The domain -specific probe EUB338 is insufficient for the detection of all Bacteria : development and evaluation of more comprehensive probe set. Systematic and Applied Microbiology, Vol.22, pp.450-459, 2001.

13) Crocetti, G. R., P.Hugenholtz, P. L. Bond, A.Schuler, J. Keller, D. Jenkins, and L. L. Blackall.: Identification of polyphosphate accumulating organisms and design of 16S rRNA-Directed Probes for Their Detection and Quantitation. Applied and Environmental Microbiology, Vol.66, pp.1175-1182, 2000.

14）日本下水道協会：平成 22 年度版 下水道統計, 2012.

15) Kong, Y., Nielsen, J. L. and Neilsen, P. H.: Idenitity and ecophysiology of uncultured actinobacterial polyphosphate-accumulating organisms in full-scale enhanced biological phosphorus removal plants. Applied and Environment Microbiology, Vol71, No.7, pp.4076-4085, 2005.

16) Julie L. Zilles, Jordan Peccia, Myeong-Woon Kim, Chun-Hsiung Hung, and Daniel R. Noguera.: Involvement of Rhodocyclus-related organisms in phosphorus removal in full-scale wastewater treatment plant. Applied and Environmental Microbiology, Vol.68, No.6, pp.2763-2769, 2002.

17) Julie L. Zilles, Jordan Peccia, Myeong-Woon kim, Chun-Hsiung and Daniel R. Noguera : Involvement of Rhodocyclus-related organisms in phosphorus removal in full-scale wastewater treatment plant. Appl. Environ. Microbiol, Vol.68, pp.2763-2769, 2002.

18) Wong M. T., Mino T., Seviour R. J., Onuki M., and Liu W. T.: In situ identification and characterization of the microbial community structure of full-scale enhanced biological phosphorus removal plants in Japan. Water Research., Vol.39, pp.2901-2914, 2005.

19) He S., Gu A. Z., and McMahon K. D.: Fine-scale differences between Accumulibacter-like bacteria in enhanced biological phosphorus removal activated sludge. Water Science Technology, Vol.54, No.1, pp.111-117, 2006.

20) Lopez-Vazquez C. M., Oehman A., Hooijmans C. M., Brdjanovic D., Gijzen H. J., Yuan Z and van Loosdrecht M. C. M.: Modeling the PAO-GAO competition : effect of carbon source, $\mathrm{pH}$ and temperature. Water Research, Vol.43, No.2, pp.450-462, 2009.

21) G. K. Morse, S. W. Brett, J. A. Guy, and J. N. Lester.: Review : Phosphorus removal and recovery technologies. The Science of the Total Environment, Vol.212, pp.69-81, 1998.

22) 市原真紀子, 西尾孝之: 浄水污泥からの凝集剂回収法とそ のリン除去能の検討. 水環境学会誌, Vol.34, No.12, pp.183-189, 2011.

23) Kato K., Murotani N., Matsufuji H., Saitoh M., and Tashiro Y. Chemical removal and recovery of phosphorus from excess sludge 
in a sewage treatment plant. Environmental Technology, Vol.27, No.5, pp.501-510, 2006

24) A. I. Zouboulis, and N. Tzoupanos : Alternative cost-effective preparation method of polyaluminium chloride (PAC) coagulant agent : Characterization and comparative application for water / wastewater treatment. Desalination, Vol.250, pp.339-344, 2010.
25) 加藤文隆, 大下和徹, 高岡昌輝, 武田信生, 松本忠生, 檜物 良一: 下水処理システムからの各種リン回収技術の仮想的適 応および評価. 土木学会論文集G, Vol.62, No.1, pp.27-40, 2006.

(2013.5. 24 受付)

\title{
Nutrient Removal and Phosphorus Recovery from Municipal Sewage Using Anaerobic/Anoxic Sequencing Batch Reactor.
}

\author{
Kenichi SAKAMOTO ${ }^{1}$, Masashi HATAMOTO ${ }^{1}$, Masanobu TAKAHASHI ${ }^{2}$, \\ Kengo KUBOTA ${ }^{2}$, Nobuo ARAKI ${ }^{3}$, Shinichi YAMAZAKI ${ }^{4}$, Tsutomu OKUBO ${ }^{5}$, \\ Shigeki UEMURA ${ }^{5}$, Hideki HARADA ${ }^{2}$, Takashi YAMAGUCHI ${ }^{1}$ \\ ${ }^{1}$ Dept. of Environmental Systems Engineering, Nagaoka University of Technology \\ ${ }^{2}$ Dept. of Civil and Environmental Engineering, Tohoku University \\ ${ }^{3}$ Dept. of Engineering, Nagaoka National College of Technology \\ ${ }^{4}$ Dept. of Environmental Civil Engineering and Architecture, Kochi National College of Technology \\ ${ }^{5}$ Dept. of Civil Engineering, Kisarazu National College of Technology
}

In this study, nitrogen and phosphorus were removed by using denitrifying phosphate-accumulating organisms (DPAOs). An anaerobic / anoxic sequencing batch reactor $\left(\mathrm{A}_{2} \mathrm{SBR}\right)$ was operated to culture the DPAOs. $\mathrm{A}_{2}$ SBR system achieved $77 \%$ of nitrogen and $83 \%$ of phosphorus removal efficiency in a system feeding actual sewage. The result showed that this system is suitable for the nutrient removal of sewage treatment. The $\mathrm{A}_{2} \mathrm{SBR}$ sample was then subjected to microbial community analysis using FISH method and the result showed that a stable treatment process was performed at $15 \%$ or more of PAOs ratio. Additionally, a hydroxyapatite precipitation (HAP) reactor was applied as the downstream system. As a result $29 \%$ of phosphorus was recovered from the sewage by the calcium-added physicochemical technology. This HAP reactor became applicable with concentration of the phosphorus around ten-fold, although influent phosphorus was as low as about $4 \mathrm{mg}-\mathrm{P} / \mathrm{L}$. 